\title{
Natural Resource Use Dilemma: A Review of Effects of Population Growth on Natural Resources in Kenya
}

\author{
George Ouma Ochola* \\ Institution of Affiliation: Rongo University, Department of Agronomy and Environmental Studies, P.O. Box 103-40404, Rongo, Kenya
}

Submission: July 05, 2018; Published: July 26, 2018

*Corresponding author: George Ouma Ochola, Institution of Affiliation: Rongo University, Department of Agronomy and Environmental Studies, Kenya, Email: jochola2012@gmail.com

\begin{abstract}
Environmental management has been a global concern for various reasons. Environment has been perceived to provide support not only to human but to other organisms as well. It forms habitat for various organisms and through support of vegetation growth ecological functions such as recharge of atmospheric moisture is realized. The ecosystems such as forests, wetlands and water play a vital role in waste assimilation. Forests act as carbon sinks and also contribute to air purification. They are also habitat for wild organisms like birds, snakes and other animals. On the other hand, wetland ecosystem offer protection services for instance the buffer zone between open water and land that regulates and protects the water from being contaminated hence pollution abatement. They also moderate climate as they contribute to the atmospheric moisture recharge. Other services offered by the wetland ecosystems include storm water abatement, provides habitats and refugia for animal and plant communities flood control, improve water quality, nutrient retention and /or recycling. Increased human population has greatly affected the environment and especially these natural resources which support both human and other life forms. Rapid population growth especially in a developing country like Kenya has put pressure on the available resources like water, forests and land in general. Increased population translates to increased demand for food and space for settlement. As a result, people engage in intensive agriculture with application of inorganic fertilizers that affect the environment negatively. They also encroach the protected areas like the Mau forest in Kenya that consequently lead to resource use conflict between the communities and the government. Population growth also lead to over exploitation of resources like forests, fish, minerals and even water. This study sought to review the impacts of population growth and the dilemma it causes on natural resources.
\end{abstract}

Keywords: Kenya; Natural Resources; Environment; Impacts; Population Growth

\section{Introduction}

The role that the environment plays in supporting various life forms cannot be overstated. The natural resources that are provided by the environment have supported human and other organisms in a number of ways. Forest for example are the acting as air purifiers. They are sources of medicine, they create microclimate as they contribute to the atmospheric moisture recharge also regulate infiltration rate. Water on the other hand is also considered the second most important resource after oxygen. It is known that all living organisms rely on it for their survival. Therefore, any that disrupts its sully and distribution, tends to disrupt the very survival of humanity and other organisms. Environment that comprises various ecosystem play a very important role in waste assimilation. Nevertheless, sustainable management and utilization of the natural resources has not been achieved [1]. Some of the factors that have this achievement a nightmare is increased human population.

\section{Results}

The consequences of increase in human population on the environment are diverse. Some of these consequences have been associated with land fragmentation, soil degradation, air pollution, pressure on water resources, and alteration of earth's climate among others. Harte (2007) recorded that environmental degradation grows in proportion to population size, assuming fixed per capita consumption and fixed modes of production, is shown to be overly optimistic. It has been noted that increase in human population impacts negatively on the environment. Harte asserted that the impacts of human population increase on the environment can be reached using the equation such as:

Environmental Impact $=$ (Population size) $\mathrm{X}$ (per-capita affluence level) X (Impact from the Technologies used to achieve that level of per-capita affluence) This implies that apart from impacts that result from direct human activities, the technology adopted in achieving the per-capita affluence also impacts the environment. For instance, the fishing methodology like use of chemicals targeting fish impacts on other aquatic organisms. The fish might also die indiscriminately as a result of the chemical sprayed on water. Similarly, water quality is also degraded by such technology. Human population continues to increase annually and the challenges it poses on the environment will be 
significant if proper environmental management strategies are not put in place. Figure 1 below indicates the world's population growth trend since 1950. Based on this information from Figure 1 , measures should be put in place monitor human population increase against the impacts it has on the environment. This figure shows the constant rise in population worldwide. This implies that a mounting pressure on the natural resources. Kenya as a developing nation falls in the class of less developed countries whose population rises rapidly as depicted in Table 1. Rise in human populations translates to increased pressure on the available resources. Demand increases with increase in human population. Mineral resources are over-exploited, extensive quarrying takes place, more vegetation is cleared to pave way for both settlement and agriculture, water resources get degraded and depleted, land is fragmented, and more waste get generated which also degrade the environment.

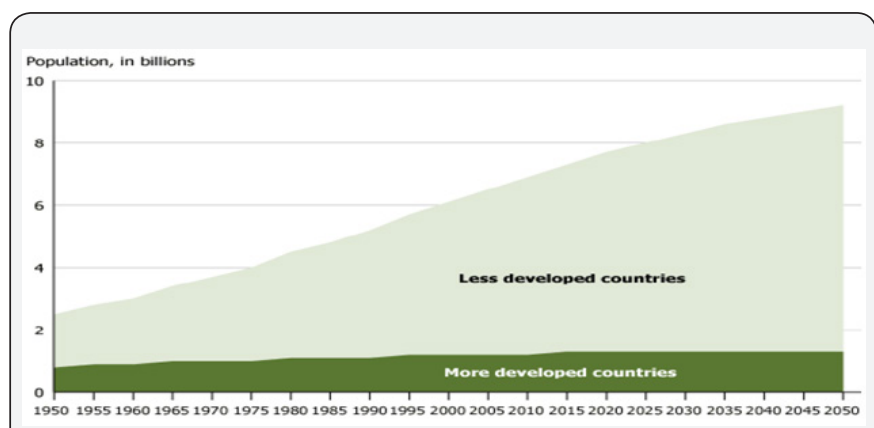

Figure 1: World Population Growth Trend Since 1950.

Table 1: Population of Kenya (2018 and historical).

\begin{tabular}{|c|c|c|c|c|c|c|c|c|c|c|c|c|}
\hline Year & Population & $\begin{array}{l}\text { Yearly \% } \\
\text { Change }\end{array}$ & $\begin{array}{l}\text { Yearly } \\
\text { Change }\end{array}$ & $\begin{array}{l}\text { Migrants } \\
\text { (net) }\end{array}$ & $\begin{array}{c}\text { Median } \\
\text { Age }\end{array}$ & $\begin{array}{c}\text { Fertility } \\
\text { Rate }\end{array}$ & $\begin{array}{c}\text { Density } \\
(\mathrm{P} / \\
\left.\mathrm{Km}^{2}\right)\end{array}$ & $\begin{array}{l}\text { Urban } \\
\text { Pop \% }\end{array}$ & $\begin{array}{c}\text { Urban } \\
\text { Population }\end{array}$ & $\begin{array}{l}\text { Country's } \\
\text { Share of } \\
\text { World } \\
\text { Pop }\end{array}$ & $\begin{array}{c}\text { World } \\
\text { Population }\end{array}$ & $\begin{array}{c}\text { Kenya } \\
\text { Global } \\
\text { Rank }\end{array}$ \\
\hline 2018 & $50,950,879$ & $2.52 \%$ & $1,251,017$ & $-10,000$ & 19.2 & 4.03 & 90 & $25.60 \%$ & $13,580,934$ & $0.67 \%$ & $7,632,819,325$ & 28 \\
\hline 2017 & $49,699,862$ & $2.56 \%$ & $1,238,295$ & $-10,000$ & 19.2 & 4.03 & 87 & $26.20 \%$ & $13,029,800$ & $0.66 \%$ & $7,550,262,101$ & 28 \\
\hline 2016 & $48,461,567$ & $2.59 \%$ & $1,225,308$ & $-10,000$ & 19.2 & 4.03 & 85 & $25.80 \%$ & $12,495,709$ & $0.65 \%$ & $7,466,964,280$ & 29 \\
\hline 2015 & $47,236,259$ & $2.70 \%$ & $1,177,221$ & $-10,000$ & 19 & 4.1 & 83 & $25.40 \%$ & $11,978,118$ & $0.64 \%$ & $7,383,008,820$ & 29 \\
\hline 2010 & $41,350,152$ & $2.78 \%$ & $1,060,373$ & $-37,866$ & 18.2 & 4.65 & 73 & $23.30 \%$ & $9,642,731$ & $0.59 \%$ & $6,958,169,159$ & 31 \\
\hline 2005 & $36,048,288$ & $2.77 \%$ & 919,561 & 5,029 & 17.6 & 5 & 63 & $21.50 \%$ & $7,756,542$ & $0.55 \%$ & $6,542,159,383$ & 33 \\
\hline 2000 & $31,450,483$ & $2.84 \%$ & 820,805 & $-4,277$ & 17 & 5.35 & 55 & $19.80 \%$ & $6,223,277$ & $0.51 \%$ & $6,145,006,989$ & 33 \\
\hline 1995 & $27,346,456$ & $3.16 \%$ & 788,790 & 44,314 & 16.4 & 5.65 & 48 & $18.30 \%$ & $5,007,379$ & $0.48 \%$ & $5,751,474,416$ & 35 \\
\hline 1990 & $23,402,507$ & $3.56 \%$ & 750,256 & 1,005 & 15.5 & 6.54 & 41 & $16.80 \%$ & $3,926,795$ & $0.44 \%$ & $5,330,943,460$ & 37 \\
\hline 1985 & $19,651,225$ & $3.85 \%$ & 676,447 & 761 & 15 & 7.22 & 35 & $16.10 \%$ & $3,161,146$ & $0.40 \%$ & $4,873,781,796$ & 37 \\
\hline 1980 & $16,268,990$ & $3.82 \%$ & 556,472 & -586 & 15 & 7.64 & 29 & $15.60 \%$ & $2,535,089$ & $0.36 \%$ & $4,458,411,534$ & 40 \\
\hline 1975 & $13,486,629$ & $3.69 \%$ & 446,827 & $-3,583$ & 15.2 & 7.99 & 24 & $12.90 \%$ & $1,741,678$ & $0.33 \%$ & $4,079,087,198$ & 45 \\
\hline 1970 & $11,252,492$ & $3.43 \%$ & 349,558 & $-3,907$ & 15.5 & 8.11 & 20 & $10.30 \%$ & $1,158,462$ & $0.30 \%$ & $3,700,577,650$ & 47 \\
\hline 1965 & $9,504,703$ & $3.24 \%$ & 279,853 & 0 & 18.9 & 7.48 & 17 & $8.60 \%$ & 817,908 & $0.28 \%$ & $3,339,592,688$ & 57 \\
\hline 1960 & $8,105,440$ & $3.04 \%$ & 225,102 & 0 & 17.2 & 7.79 & 14 & $7.40 \%$ & 596,757 & $0.27 \%$ & $3,033,212,527$ & 55 \\
\hline 1955 & $6,979,931$ & $2.81 \%$ & 180,635 & 0 & 18.9 & 7.48 & 12 & $6.40 \%$ & 448,051 & $0.25 \%$ & $2,772,242,535$ & 57 \\
\hline
\end{tabular}

As stated above, the Kenyan population has been growing at a faster rate. The information received from the department of Economic and Social Affairs, Population Division. World Population Prospects: The 2017 Revision, (Medium-fertility variant) retrieved from Worldometers (www.worldometers. info) on $5^{\text {th }}$ July 2018 justifies how fast the Kenyan population grows.

\section{Impacts of Human Population Growth on Water Resources}

As was mentioned earlier, water is natural resources with a lot of significance to human and other organisms' lives. It constitutes a larger percentage of human body fluid. A part from being used for drinking and other domestic purposes, it supports agricultural activities, transport, industries and provides habitat for aquatic organisms. The increased human population has put a lot of pressure on water resources [2]. Several shallow wells and bore holes have been dug and drilled to supply water for various uses. The underground water is been over-withdrawn and this in turn impacts on the water cycle [3]. Water resources may seem to be abundant but it is worth noting that the Oceans and Seas contain $96-97 \%$ of the world's while the glaciers and polar icecaps constitutes 2-3\%. It therefore implies that only less than one $(1 \%)$ is the fresh water that can be used by directly by man. The other percentage locked in Oceans and seas is salty and cannot be used directly for agriculture, industry and domestic purposes. The less than one percent fresh water is also shared by many competing users hence vulnerability and dilemma of water resource use.

Human population increase results in intense agricultural practices. It leads to destruction of water towers and catchment areas such as Mau Forest in Kenya. The inorganic fertilizers applied to improve yields to cater for the needs of increased 
population not only impacts negatively on soil but also finds its way to water bodies either through run off or other means. This degrades water quality. This can contribute to eutrophication and at the same time interfere with the $\mathrm{pH}$ of water thereby affecting the aquatic biodiversity [4]. Intensive agriculture practiced as a result of human population has also called for irrigation activities which at times involve overutilization of water. Population growth is also associated with generation of more waste which because of lack of knowledge in their management may be dumped directly into the water bodies hence degrading the quality of water [5]. Similarly, overpopulation or rapid increase in population could be associated with increased poverty level. Due to this fact, more water resources like fish may be over-exploited. Their harvesting may take any form like use of chemicals in fishing which might not only impact on the fish species but can as well harm other aquatic organisms [6]. The chemical sprayed on water reduces dissolved oxygen concentration thereby interfering with the aquatic biodiversity. These chemicals also degrade water quality. Several industries have also been established based on the increased demand created by human population increase. These industries contribute positively to the development of any nation. However, their impact on water resources remains and issue of concern [7]. The industries put pressure on the available water resources considering the fact that only less than $1 \%$ is the only water available (fresh) to be used directly for human consumption and other activities. Equally, the effluents from the industries at times contaminate water bodies. The treatment of the industrial effluents might not be $100 \%$ effective. Some heavy metals may find their way into the water systems hence degrading the quality. Some industries also contribute to the emission of carbon dioxide and other greenhouse gases into the atmosphere [8]. They are also contributors of sulphur dioxide and oxides of nitrogen. These get into the atmosphere and mix with the precipitation as it rains to form acid rains. The acid rains affect not only some species of plants that cannot withstand salty conditions but also affect the water $\mathrm{pH}$ hence interfere with aquatic biodiversity.

\section{Population Growth and Forest Resources}

The roles played by forests and/or vegetation cannot be over emphasized. Forests are attached to aesthetic value addition, attraction sites for tourists, provide recreational space, contribute in nutrient recycling, purify air by acting as carbon sinks, control soil erosion and rate of infiltration, provide habitats for various biodiversity, are sources of medicine, source of fuel and raw materials for industries especially the paper milling industries. Based on those roles which are not exhausted in this paper, forests and/or vegetation require proper management, protection and conservation. The increase in human population has put a lot of pressure on forest resources as was indicated in Figure 2 that the year 2000 area under forest cover in had dropped to 35000 square Km from 47240 in 1990. Although forest cover seemed to have increased between the year 2000 and 2015 (35570 to 44130 square $\mathrm{Km}$ ), Kenyan population increase as depicted in Table 1 signifies threat on the forest cover. Table 2 shows the constant increased in settlement areas and the crop lands. This implies that as population increases, more land is needed for settlement. The vegetation is replaced with structures and their ecological roles are compromised. The built up environment increases in coverage. The impacts associated with built environment are also carried on. Similarly, the crop lands also increase to help provide more food to cater for the increased population. The resultant agricultural effects are felt on the environment. These include alteration of soil $\mathrm{pH}$ through addition of excess inorganic fertilizers, elimination of some soil micro-organisms that like earth warms that may be die as a result of the chemical component of the inorganic fertilizers. In addition, intensive agriculture make the soil lose its nutrients and also loosen the soil compactness hence making it susceptible agents of soil erosion. Due to increased human population, there had been deforestation either for firewood, or charcoal burning for sale and other domestic uses. The forest gets depleted and as this happens, there is loss of biodiversity as some species that cannot regenerate after being cut die. The habitat for some species are destroyed making them to migrate. Some forest fires are also cause which lead to mass destruction of these ecosystem. According to Baus increased human population leads to scramble for forest resources which at times cause human conflicts. It has been noted that Kenyan population will continue to grow and the impacts of this increase on forest resources will be significant. Figure 3 shows the Kenyan population growth trend and the projection up to 2050 .

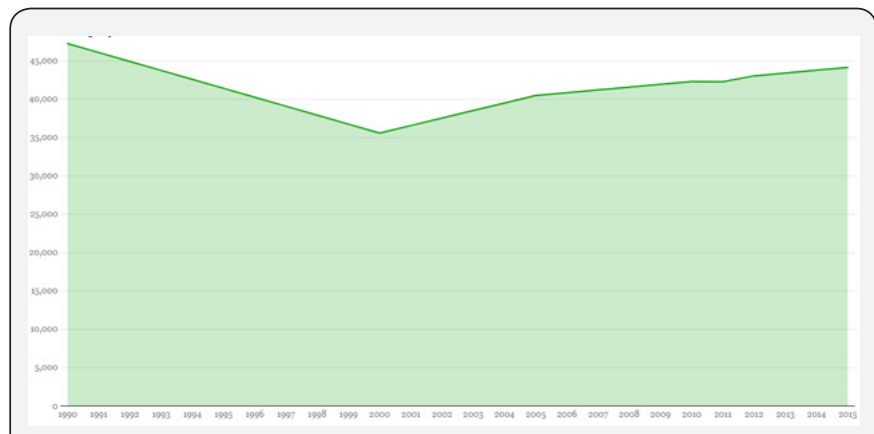

Figure 2: Kenya Forest Cover Changes since 1990.

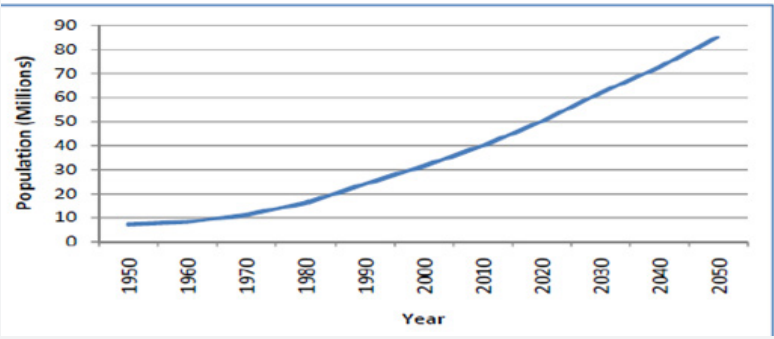

Figure 3: Past (1950 - 2009) and projected trends (2010 - 2050) in population growth in Kenya between based on the current $3 \%$ growth rate.

Source: Imo, (2014) 
Table 2: Changes in Forest, Cropland, Settlements, Grassland and other lands since 1990 in Kenya.

\begin{tabular}{|c|c|c|c|c|c|}
\hline \multirow{2}{*}{$\begin{array}{c}\text { Name of } \\
\text { Variable }\end{array}$} & \multicolumn{5}{|c|}{ Area ('oooHa) } \\
\cline { 2 - 6 } & $\mathbf{1 9 9 0}$ & $\mathbf{2 0 0 0}$ & $\mathbf{2 0 0 5}$ & $\mathbf{2 0 1 0}$ & $\mathbf{2 0 1 5}$ \\
\hline Forestland & 4724 & 3557 & 4047 & 4230 & 4413 \\
\hline Cropland & 9258 & 9661 & 9868 & 10072 & 10276 \\
\hline Grassland & 41522 & 41654 & 41496 & 41080 & 40664 \\
\hline Settlements & 57 & 87 & 109 & 126 & 143 \\
\hline Otherlands & 1004 & 1574 & 1035 & 1044 & 1053 \\
\hline Wetlands & 1472 & 1504 & 1482 & 1485 & 1488 \\
\hline $\begin{array}{c}\text { Total Area } \\
\text { for country }\end{array}$ & 58037 & 58037 & 58037 & 58037 & 58037 \\
\hline
\end{tabular}

When forest is depleted, there will be accumulation of a lot of greenhouse gases in the atmosphere. As it is known by some of us, greenhouse gases such as Carbon dioxide and water vapour together with methane have the ability to absorb infrared radiation. When they get into the atmosphere in abundance, they normally trap the infrared radiation which emitted back into the space by the earth. This intensifies the greenhouse effect hence contributing to global warming. Considering the important roles played by the vegetation, there need to adopt appropriate strategies in management and conservation of forest resources. This is because the Kenyan human population will continue to rise as projected in Figure 3.

\section{Conclusion}

Considering the ever-rising graph in the Kenyan population, it implies that the natural resources in Kenya are and will continue be subjected a lot of pressure in order to meet the human needs. The resources are rapidly getting depleted and this poses fear to the future generation. As was mentioned earlier, human's life together with the lives of other organisms on earth depend on the environment. Despite this fact, there has been little consideration by man that it is these resources that support his life. Man has been disposing off waste indiscriminately, wash directly in river and lake waters, degrades forest resources, turn wetlands into settlement and agricultural lands, encroach and put structures in wildlife protected areas, dump waste and direct sewer lines into river systems and does a lot of harm to the environment. It is imperative to realize that it these resources that hold our lives on earth. That is, they own us and not us owning them. Thus, we should treat, manage and conserve them appropriately and where need be, we protect them.

\section{Recommendations}

The following can be recommended based on this review study:

a) Awareness creation on sustainable natural resource use strategies.

b) Encouraging agro-forestry.

c) Encouraging the use of renewable sources of energy.

d) Promotion of afforestation programmes.

e) Policy enforcement for proper use of forest and water resources.

f) Advocating for proper waste management.

\section{References}

1. Asongu SA, Jingwa BA (2011) Population growth and forest sustainability in Africa.

2. Chamara PL, Koichi Y (2017) Impact of Population Growth on the Water Quality of Natural Water Bodies: Sustainability Article. Department of Information Science and Control Engineering, Nagaoka University of Technology.

3. Chinedu MP, Mbee MD (2013) Population Pressure and Forest Resources Depletion in Gele -Gele Forest Reserve of Edo State, Nigeria. International Journal of Physical and Human Geography 1(3).

4. Doris B (2017) Overpopulation and the Impact on the Environment. A master's thesis. The Graduate Center, City University of New York, USA.

5. Edet SI, Nnaji ES, Asuquo EE, Etefia TE (2014) Impact of Overpopulation on the Biological Diversity Conservation in Boki Local Government Area of Cross River State, Nigeria. American Journal of Environmental Engineering 4(5): 94-98.

6. Global Forest Resources Assessment 2015 (Country Report Kenya Rome, 2014).

7. Harte J (2007) Human population as a dynamic factor in environmental degradation. Popul Environ Springer Science + Business Media, LLC 2007 28: 223-226.

8. Imo M (2014) Forest Degradation in Kenya: Impacts of Social, Economic and Political Transitions.

\section{Your next submission with Juniper Publishers} will reach you the below assets

- Quality Editorial service

- Swift Peer Review

- Reprints availability

- E-prints Service

- Manuscript Podcast for convenient understanding

- Global attainment for your research

- Manuscript accessibility in different formats

( Pdf, E-pub, Full Text, Audio)

- Unceasing customer service

Track the below URL for one-step submission https://juniperpublishers.com/online-submission.php 